\title{
PENERAPAN MODEL POE2WE DENGAN PENDEKATAN SAINTIFIK DALAM PEMBELAJARAN TORSI, MOMEN INERSIA, TITIK BERAT, MOMENTUM SUDUT PADA BENDA TEGAR DI SMA IPA KELAS XI
}

\author{
Affaf Husain ${ }^{*}$, Nana ${ }^{2}$ \\ ${ }^{1}$ Mahasiswa Pendidikan Fisika, Universitas Siliwangi \\ ${ }^{2}$ Dosen Pendidikan Fisika, Universitas Siliwangi \\ *email korespondensi: affafhusain7@gmail.com
}

\begin{abstract}
:
The purpose of this paper is to describe the application of the POE2WE model with a scientific approach so that students more easily understand torque learning material, moments of inertia, center of gravity, angular momentum on rigid objects, students are more active in teaching and learning activities and students can make the process of finding knowledge regarding with the study material they learn. The methodology used in this paper is to use a library research method or approach. The results of this paper show that the application of the POE2WE model with a scientific approach makes it easier for students to understand the material and is more active in learning activities, especially in learning torque, moment of inertia, center of gravity, angular momentum on rigid objects in high school science class XI.
\end{abstract}

Keywords: POE2WE Model, Scientific Approach, Literature Study, Natural Science Senior High School

\section{Abstrak:}

Tujuan tulisan ini adalah mendeskripsikan penerapkan model POE2WE dengan pendekatan saintifik agar peserta didik lebih mudah memahami materi pembelajaran torsi, momen inersia, titik berat, momentum sudut pada benda tegar, peserta didik lebih aktif dalam kegiatan belajar mengajar dan peserta didik dapat melakukan proses pencarian pengetahuan berkenaan dengan materi pelajaran yang dipelajarinya. Metodologi yang digunakan dalam tulisan ini yaitu menggunakan metode atau pendekatan kepustakaan (library research). Hasil dari penulisan ini menunjukan bahwa penerapan model POE2WE dengan pendekatan saintifik menjadikan peserta didik lebih mudah memahami materi dan lebih aktif dalam kegiatan belajar khususnya dalam pembelajaran torsi, momen inersia, titik berat, momentum sudut pada benda tegar di SMA IPA kelas XI.

Kata Kunci: Model POE2WE, Pendekatan Saintifik, Studi Pustaka, SMA IPA

\section{PENDAHULUAN}

Fisika merupakan bagian dari ilmu pengetahuan alam. Fisika juga merupakan bagian ilmu pengetahuan yang bersinggungan dengan mata pelajaran lain seperti biologi dan kimia. Oleh karena itu Fisika menjadi salah satu mata pelajaran yang penting untuk dipelajari. Akan tetapi $60 \%$ dari siswa berpendapat bahwa fisika adalah pelajaran yang sulit dipahami dan kurang menarik dipelajari (Silalahi dalam Nana, 2019). Hal ini dikarenakan model pembelajaran yang sangat sering 
digunakan adalah model pengajaran tradisional yakni ceramah, jarang sekali menggunakan model yang bervariasi.

Fisika adalah mata pelajaran yang sukar bagi siswa (Osborn, J., dkk: 2003). Fisika adalah satu dari mata pelajaran yang sukar di sekolah lanjutan (Bascones, J., dkk: 1985).

Pemahaman konsep merupakan salah satu faktor penting dalam pembelajaran fisika. Hal ini berarti siswa tidak hanya menghafal materi fisika semata, namun siswa lebih diharapkan agar mampu mengetahui peran dan manfaat fisika sebagai ilmu terapan di kehidupan. Pemahaman konsep adalah kemampuan siswa dalam menerjemahkan, menafsirkan, dan menyimpulkan suatu konsep atau kemampuan menangkap makna arti suatu konsep (Sanjaya, 2008: 126). Pemahaman konsep merupakan dasar dari Pemahaman prinsip-prinsip teori, artinya agar dapat memahami prinsip dan teori harus dikuasai terlebih dahulu konsep-konsep yang menyusun prinsip tersebut. Pemahaman konsep m erupakan suatu upaya ke arah pemahaman siswa untuk memahami hal-hal lain di luar pengetahuan sebelumnya.

Ada beberapa materi keseimbangan benda tegar yang masih sulit dipahami oleh siswa yaitu momen inersia, momen gaya, titik berat dan momentum sudut. Pada materi momen inersia, siswa memiliki kesulitan dalam penentuan arah dan besarnya jarak partikel ke posisi sumbu putar. Pada materi momen gaya, siswa masih banyak yang kesulitan dalam menentukan arah perputaran momen gaya. Pada materi titik berat, masih terdapat beberapa siswa yang menganggap bahwa titik berat benda selalu berada di tengah benda. Padahal tidak semua benda memiliki titik berat di tengah benda.

Salah satu yang dapat meminimalisir kesulitan adalah memilih model dengan pendekatan pembelajaran yang tepat untuk digunakan dalam proses belajar. Tulisan ini akan membahas pembelajaran dengan menerapkan model POE2WE dengan pendekatan saintifik agar peserta didik lebih mudah memahami materi pembelajaran torsi, momen inersia, titik berat, momentum sudut pada benda tegar, peserta didik lebih aktif dalam kegiatan belajar mengajar dan peserta didik dapat melakukan proses pencarian pengetahuan berkenaan dengan materi pelajaran yang akan dipelajarinya.

\section{METODE PENELITIAN}

Metode yang digunakan dalam tulisan ini menggunakan metode atau pendekatan kepustakaan (library research). Studi pustaka atau kepustakaan dapat diartikan sebagai serangkaian kegiatan yang berkenaan dengan metode pengumpulan data pustaka, membaca dan mencatat serta mengolah bahan penelitian (Zed, 2003:3).

Kajian pustaka atau studi pustaka merupakan kegiatan yang diwajibkan dalam penelitian, khususnya penelitian akademik yang tujuan utamanya adalah mengembangkan aspek teoritis maupun aspek manfaat praktis (Sukardi, 2013).

Dalam penelitian studi pustaka setidaknya ada empat ciri utama yang penulis perlu perhatikan diantaranya: Pertama, bahwa penulis atau peneliti berhadapan langsung dengan teks (nash) atau data angka, bukan dengan pengetahuan langsung dari lapangan. Kedua, data pustaka bersifat "siap pakai" artinya peniliti tidak 
terjung langsung kelapangan karena peneliti berhadapan langsung dengan sumber data yang ada di perpustakaan. Ketiga, bahwa data pustaka umumnya adalah sumber sekunder, dalam arti bahwa peneliti memperoleh bahan atau data dari tangan kedua dan bukan data orisinil dari data pertama di lapangan. Keempat, bahwa kondisi data pustaka tidak dibatasi oleh runga dan waktu (Zed, 2003:4-5).

\section{HASIL DAN PEMBAHASAN}

\subsection{Pengertian POE2WE}

Menurut Nana (2018) Model pembelajaran Prediction, Observation, Explanation, Elaboration, Write dan Evaluation (POE2WE) dikembangkan dari model pembelajaran POEW dan model pembelajaran Fisika dengan Pendekatan Konstruktivistik. Model POE2WE merupakan model pembelajaran yang dikembangkan untuk mengetahui pemahaman siswa mengenai suatu konsep dengan pendekatan konstruktivistik. Model ini membangaun pengetahuan dengan urutan proses terlebih dahulu meramalkan atau memprediksi solusi dari permasalahan, melakukan eksperimen untuk membuktikan prediksi, kemudian menjelaskan hasil eksperimen yang diperoleh secara lisan maupun tertulis, membuat contoh penerapan dalam kehidupan sehari-hari, menuliskan hasil diskusi dan membuat evaluasi tentang pemahaman siswa baik secara lisan maupun tertulis.

Model pembelajaran POE2WE dapat menjadikan siswa sebagai subjek di dalam pembelajaran. Siswa aktif dalam menemukan suatu konsep melalui pengamatan atau eksperimen secara langsung, bukan dari menghafal buku materi maupun penjelasan dari guru. Model ini memungkinkan siswa aktif dalam proses pembelajaran, memberikan kesempatan kepada siswa untuk mengkonstrukssi pengetahuannya, mengkomunikasikan pemikirannya dan menuliskan hasil diskusinya sehingga siswa lebih menguasai dan memahami konsep yang akan berdampak pada peningkatan prestasi belajar siswa. Hal tersebut sesuai dengan pendapat Permatasari (2011:1) bahma model ini memberikan kesempatan kepada siswa untuk mengkonstruksi pengetahuannya sendiri, melakukan pengamatan terhadap fenomena serta mengkomunikasikan pemikiran dan hasil diskusi sehingga siswa akan lebih mudah menguasai konsep yang di ajarkan.

\subsection{Pengertian Pendekatan Saintifik}

Pembelajaran saintifik merupakan pembelajaran yang mengadopsi langkahlangkah saintis dalam membangun pengetahuan melalui metode ilmiah. Model pembelajaran yang diperlukan adalah yang memungkinkan terbudayakannya kecakapan berpikir sains, terkembangkannya "sense of inquiry" dan kemampuan berpikir kreatif siswa (Alfred De Vito dalam Nana, 2018). Model pembelajaran yang dibutuhkan adalah yang mampu menghasilkan kemampuan untuk belajar (Joice \& Weil dalam Nana, 2018), bukan saja diperolehnya sejumlah pengetahuan, keterampilan, dan sikap, tetapi yang lebih penting adalah bagaimana pengetahuan, keterampilan, dan sikap itu diperoleh peserta didik (Zamroni, 2000; \&Semiawan, 1998).

Pembelajaran saintifik tidak hanya memandang hasil belajar sebagai muara akhir, namum proses pembelajaran dipandang sangat penting. Oleh karena itu 
pembelajaran saintifik menekankan pada keterampilan proses. Model pembelajaran berbasis peningkatan keterampilan proses sains adalah model pembelajaran yang mengintegrasikan keterampilan proses sains ke dalam sistem penyajian materi secara terpadu (Beyer dalam Nana, 2018). Model ini menekankan pada proses pencarian pengetahuan dari pada transfer pengetahuan, peserta didik dipandang sebagai subjek belajar yang perlu dilibatkan secara aktif dalam proses pembelajaran, guru hanyalah seorang fasilitator yang membimbing dan mengkoordinasikan kegiatan belajar (Nana, 2018).

Dalam model ini peserta didik diajak untuk melakukan proses pencarian pengetahuan berkenaan dengan materi pelajaran melalui berbagai aktivitas proses sains sebagaimana dilakukan oleh para ilmuwan (scientist) dalam melakukan penyelidikan ilmiah (Nur dalam Nana: 2018), dengan demikian peserta didik diarahkan untuk menemukan sendiri berbagai fakta, membangun konsep, dan nilainilai baru yang diperlukan untuk kehidupannya. Fokus proses pembelajaran diarahkan pada pengembangan keterampilan siswa dalam memproseskan pengetahuan, menemukan dan mengembangkan sendiri fakta, konsep, dan nilainilai yang diperlukan (Semiawan dalam Nana, 1992).

\subsection{Torsi, Momen Inersia, Titik Berat dan Momentum Sudut pada Benda Tegar}

Pemahaman konsep pada materi momen gaya digunakan untuk mengetahui pemahaman peserta didik dalam menentukan jenis-jenis keseimbangan dan menganalisis masalah yang memuat konsep torsi. Pemahaman konsep pada materi momen inersia ditujukan pada pemahaman konsep siswa terhadap persamaan momen inersia serta penerapannya dalam suatu masalah. Pemahaman konsep pada materi momen inersia ditujukan pada pemahaman konsep siswa terhadap definisi pusat gravitasi atau titik berat dan menentukan titik berat pada benda-benda homogen. Dan konsep momentum sudut yaitu hasil kali antara momen inersia dan kecepatan sudutnya.

\subsection{Penerapan Model POE2WE dengan Pendekatan Saintifik dalam Pembelajaran Torsi, Momen Inersia, Titik Berat, Momentum Sudut pada Benda Tegar di SMA IPA Kelas XI}

Pembelajaran yang digunakan agar peserta didik memahami konsep adalah dengan pendekatan saintifik. Pembelajaran fisika dengan pendekatan saintifik mengedepankan siswa memperoleh konsep melalui kegiatan secara aktif dan bersentuhan langsung terhadap fenomena pada kehidupan sehari-hari sehingga dapat meningkatkan hasil belajar siswa. Hal tersebut sesuai dengan pernyataan (Macaulay, Damme \& Walker, 2009) bahwa Active student-centered learning mendorong pendekatan yang lebih dalam untuk belajar dan dapat meningkatkan hasil belajar.

Menurut Nana (2018) pembelajaran dengan pendekatan saintifik melalui model POE2WE ini antara lain adalah terletak pada tahap predict, guru menyajikan permasalahan yang di bagikan ke peserta didik. Kegiatan pembelajaran tahap observe yaitu melakukan eksperimen. Lalu pada tahap explain peserta didik mempresentasikan hasil diskusi kelompoknya dan ditanggapi oleh kelompok lain. 
Pengembangan lainnya yaitu pada saat guru memberikan penjelasan atau konfirmasi terhadap suatu konsep yang masih kurang benar, guru menampilkan video agar siswa lebih jelas dalam memahami materi. Sebelum ketahap write di tambahkan tahap elaboration yaitu penerapan konsep torsi, momen inersia, titik berat, dan momentum sudut pada benda tegar dalam kehidupan sehari-hari. Pada tahap write siswa tidak hanya membuat kesimpulan hasil permasalahn yang diberikan oleh guru, tetapi juga membuat peta konsep serta laporannya.

\section{PENUTUP}

Dari berbagai pembahasan yang telah dijabarkan dapat ditarik kesimpulan dan dimaknai bahwa model POE2WE dengan pendekatan saintifik dapat memudahkan peserta didik dalam memahami materi pembelajaran torsi, momen inersia, titik berat, momentum sudut pada benda tegar, peserta didik lebih aktif dalam kegiatan belajar mengajar dan peserta didik dapat melakukan proses pencarian pengetahuan berkenaan dengan materi pelajaran yang dipelajarinya.

\section{UCAPAN TERIMA KASIH}

Terima kasih kepada Dr. Nana., M. Pd selaku dosen pengampu yang telah membantu demi kesempurnaan jurnal ini menjadi lebih baik.

\section{DAFTAR PUSTAKA}

Bascones, J., Novak, V., \& Novak, J. D. (1985). Alternative instructional systems and the development of problem-solving skills in physics. European Journal of Science Education, 7(3), 253- 261.

Fitrianingrum, Aufa Maulida., dkk.(2017). Penerapan Instrumen Three-Tier Test untuk Mengidentifikasi Miskonsepsi Siswa SMA pada Materi Keseimbangan Benda Tegar.

Larkin, J. H., dan Reif, F. (1979). Understanding and teaching problem-solving in physics. European Journal of Science Education, 1(2), 191-203.

Macaulay J O Damme V and Walker K Z.(2009). The Use of Contextual Learning to Teach Biochemistry to Dietetic Students (Biochemistry and Molekular Biology Education). vol 37 no 3 pp 137-143

Nana.(2018). Implementasi Model POE2WE dengan Pendekatan Saintifik dalam Pembelajaran Gerak Lurus Di SMA.

Nana, Hadi Pramono.(2019). Upaya Peningkatan Kemampuan Kognitif dan Komunikasi Ilmiah Siswa Kelas X MIA 1 SMA Negeri 1 Ciamis Menggunakan Model Pembelajaran Inquiry.

Osborne, J., Simon, S. \& Colins, S. (2003). Attitudes towards science: A review of the literature and its implications. International Journal of Science 
Education [Online], Vol 25(9), 1049-1080. Tersedia: http:// opas.ous.edu/Committees/Resources/Publications/AttitudesOsborne_IntJ SciEduc_2003.pdf. [08 Februari 2020]

Sanjaya, W. (2008). Perencanaan dan Desain Sistem Pembelajaran. Jakarta: Kencana

Sukardi.(2013). Metodologi Penelitian Pendidikan Kompetensi dan Praktiknya.Jakarata : PT Bumi Aksara,2013, h.33

Zed, Mestika.(2003). Metode Penelitian Kepustakaan. Jakarta : Yayasan Obor Indonesia 